\title{
Educational Inequality in the EU
}

\author{
The Effectiveness of the National \\ Education Policy
}

\author{
Raphaela Schlicht \\ University of Konstanz, Germany \\ Isabelle Stadelmann-Steffen \\ University of Konstanz, Germany \\ Markus Freitag \\ University of Konstanz, Germany
}

\section{KEY WORDS}

- education

- European Union

- inequality

- multi-level analysis

- new institutionalism

- policy 


\section{Introduction}

Since the publication of the Programme for International Student Assessment (PISA) by the Organisation for Economic Co-operation and Development (OECD), a lively discussion about the performance and effectiveness of education policies has begun in Europe. This debate has focused also on the high degree of social inequality that is manifest in many countries. We contribute to these discussions with a systematic evaluation of the influence that national education policies have on social inequality in education within the member states of the European Union (EU). As a prototype of supranational organizations, the EU provides a vast framework of supranational rules and emphasizes the goal of promoting 'system equity' in education (Drezner, 2001; Green, 1999; Knill, 2005). Nevertheless, there is a substantial literature that challenges the convergence of social policies and their outcomes within the EU (Alber, 2006; Dimitrova and Steunenberg, 2000). In fact, both the Third International Mathematics and Science Study (e.g. Beaton et al., 1996) and PISA (Baumert et al., 2001) demonstrate that the extent of social inequality in education varies among EU members. The relationship between individual social background and education assessment therefore remains a nationspecific parameter. Particularly for the EU context, the diversity with regard to educational inequality is a central issue, because comparable quality of life standards are essential for the advancement of the European integration process (see Kritzinger, 2003). This leads us to our central question: Which policy conditions are responsible for the national extent of social inequality in education within the EU member states? ${ }^{1}$

The dependence of educational performance on individuals' social background plays a pivotal role in public affairs for at least three reasons. First, the dependence of educational attainment on social background, rather than on individual capabilities, is seen as a waste of human capital (Handl, 1985). A society's investment in education is a prerequisite for future economic and technical competitiveness. Second, the transmission of social background from parents to children via education leads to an inheritance of status that circumvents a meritocratic allocation of social goods (Solga, 2005). Social inequality in education is, therefore, seen as a foundation for future inequalities (Allmendinger and Leibfried, 2003; Müller and Pollak, 2004). Third, educational equality is also relevant for the functioning of democracies (Coleman, 1979). Preston and Green (2005), for example, observe negative effects of social inequality in education on aspects of social trust as well as political and civil freedom. Therefore, a school policy's capacity to produce social equality plays a major role in today's welfare state (Schneider and Keesler, 2007; Wilensky, 1975). 
Although there is a rapidly growing body of work assessing the effects of individual social background on educational performance, little or no empirical research has been conducted with regard to the macro foundations of educational inequality. Several examinations of the policy conditions of educational inequality refer to the US context (Coleman, 1979; Reed, 2003). However, international comparisons of education policies and their outcomes are quite rare (for an exception see Schütz et al., 2005). The present study therefore includes several educational conditions (availability of preschool education, all-day school tradition, tracking during secondary education, private school sector, average class size, education expenditures) that appear to be of relevance for the EU member states. Our approach is to use hierarchical models to illuminate the moderating impact of education policy conditions on the relationship between individual social background and individual educational performance in a systematic comparative manner. Because individual attitudes and behaviour are structured both by personal traits and by the social context (Anderson and Singer, 2008; Levels et al., 2008), this methodology is seen as a tried and tested means for overcoming the micro/macro dualism in empirical research.

The article is organized as follows. In the next section, we conceptualize social inequality in education and present descriptive evidence of how unequal education within the EU member states is. We then present our theoretical framework and derive hypotheses from it that explain the varying degrees of social inequality. After explaining the measurements of the individual- and contextual-level variables and the methodological approach of the multi-level analyses, we present our results and evaluate our hypotheses. We conclude with a summary and a discussion of our major findings.

\section{Social inequality in education within the EU}

The core concept of this study is social inequality in education within the EU. In accordance with Jacobs (1996), we focus on social inequality in the school education process. We therefore conceptualize social inequality in education as the dependence of pupils' mathematical capabilities on the individual social background. Because maths syllabuses are nearly identical all over the world, mathematical capabilities are chosen as the indicator by which to compare individual success in school. We presume social inequality in the school education process to be the most appropriate concept to illustrate the differing degrees of social inequality of education in the EU. International comparisons of educational inequality mostly refer to inequality in the education process, because the level of capabilities attained is the trait that 
best lends itself to comparison among groups of states with widely varying education policies. Jacobs (1996) distinguishes two further concepts of educational inequality: social inequality of educational access and inequality of educational outcome.

The reasons we rely on an indicator for inequality of the educational process are twofold. First, the degree of school educational access is difficult to compare in the international context. The differentiation between and the organization of school levels differ markedly between the units of analysis, thereby rendering the investigation of access to a particular school level impossible. Second, social inequality of educational outcome is not what this study aims to investigate. Inequality of educational outcome describes socially unequal occupational opportunities (access to higher education or specific occupations). The assumption of this study, however, is that early inequalities in school education represent the foundations of later inequalities. Consequently, the focus of this study is on social inequality in the school educational process.

During the 1980s, social inequality in education was predicted to take a back seat owing to a widespread general expansion of education within industrialized societies (Erikson and Goldthorpe, 1992; Solga and Wagner, 2001). The 2006 PISA data definitely disprove this assumption, demonstrating that social inequality in education continues to persist in modern and developed countries. Furthermore, it can be revealed that the extent of social inequality in education varies between political entities, pointing to a possible macro societal foundation (von Carnap and Edding, 1962). The 2006 PISA survey offers the most up-to-date comparative information on pupils' social background and their educational performance. ${ }^{2}$ In order to illustrate the influence of social background on pupils' school attainment, we estimate OLS regressions for each EU country. The regression coefficients of social background describe the impact that social background has on pupils' educational achievement in each EU country. The proxy for individual social background is the highest level of education attained by the parent(s). Our measurement of social background thus pursues a cultural capital approach. Following Bourdieu (1983: 186), although the transmission of cultural capital within the family is the least transparent, it is socially the most effective educational investment. Parental educational attainment implies certain capacities to transfer knowledge between generations and is therefore used in many studies as a measure of cultural capital at home (Barone, 2006; Blossfeld and Shavit, 1993). Table 1 illustrates the great variation of social inequality in education within the EU.

Social inequality is lowest in Romania (2.69) and highest in Hungary (23.53). Whereas an increase in parental educational attainment by one unit 
Table 1 Regression coefficients for the impact of parental educational attainment on pupils' mathematical capabilities: Mean of Western EU compared with mean of Eastern EU

\begin{tabular}{|c|c|}
\hline & $\begin{array}{l}\text { Social inequality } \\
\text { in education }\end{array}$ \\
\hline \multicolumn{2}{|c|}{ Western EU countries } \\
\hline Portugal & 5.96 \\
\hline Netherlands & 6.45 \\
\hline Austria & 6.46 \\
\hline Sweden & 6.65 \\
\hline Great Britain & 7.11 \\
\hline Luxembourg & 7.72 \\
\hline Italy & 8.36 \\
\hline Denmark & 8.69 \\
\hline Finland & 9.53 \\
\hline Spain & 9.66 \\
\hline France & 10.47 \\
\hline Ireland & 11.40 \\
\hline Germany & 13.18 \\
\hline Belgium & 13.34 \\
\hline Greece & 15.74 \\
\hline Mean & 9.38 \\
\hline \multicolumn{2}{|c|}{ Eastern EU countries } \\
\hline Romania & 2.69 \\
\hline Estonia & 8.07 \\
\hline Latvia & 10.64 \\
\hline Slovenia & 14.29 \\
\hline Bulgaria & 14.37 \\
\hline Lithuania & 15.40 \\
\hline Poland & 20.55 \\
\hline Czech Republic & 21.17 \\
\hline Slovakia & 22.23 \\
\hline Hungary & 23.53 \\
\hline Mean & 15.29 \\
\hline
\end{tabular}

Note: Regression coefficients of parents' education from country-specific multiple OLS regressions including the following controlling variables: gender, cultural possessions, home possessions, first-generation foreigner, language of test differs from language spoken at home.

raises pupils' maths capabilities by only 2.69 units in Romania, the same increase in parents' education raises maths capabilities by 23.53 units in Hungary. This example illustrates the vast differences between the EU member states concerning the degree of social inequality in education. 
Moreover, two clusters of countries can be observed: there are obvious differences in social inequality in education between the West European and the post-communist member states. With the exception of Romania, educational performance is much more dependent on social background in the Eastern EU countries than in Western Europe. Against this background, and with regard to the striking differences between the countries, it is relevant to ask whether the persistence of national education policies within the EU is responsible for the extent of social inequality in education. ${ }^{3}$

\section{Theoretical accounts - the relationship between national education policy and social inequality in education}

The previous section has shown that the degree of social inequality varies considerably among the EU member states. Following the advice of educational sociologists (Becker, 2000; Dronkers, 1993), we introduce a policycentred approach to explain the differing degrees of educational inequality between these units and to evaluate the effectiveness of national education policy. Taking a political science perspective, our main goal is to investigate whether the inequalities result from persistent national differences in school policies. Until now a comprehensive theory on how education policy influences educational outcomes has been lacking. Our contribution must therefore be seen as a first step towards such a theoretical approach. On the one hand, we are looking for the crucial aspects and dimensions of education policy, and thus focus on the following six measures characterizing the educational process: availability of preschool education, all-day school tradition, tracking during secondary education, private school sector, class size and education expenditures (see Figure 1). On the other hand, in order to understand how and why certain policy instruments generate a particular aggregate outcome, a proper appreciation of the processes at the individual level needs to be taken into account (Hedström and Swedberg, 1996: 131). We therefore analyse the micro mechanisms behind the macro relationships observed, i.e. how the relationship between social status and educational performance (horizontal arrow in Figure 1) is moderated by education policy variables (vertical arrow in Figure 1). According to the core tenets of the New Institutionalism literature, institutional rules, procedures and conventions mould individual preferences, thereby encouraging or limiting behavioural options by means of certain incentive mechanisms (Hall and Taylor, 1996; Immergut, 1998; Ostrom, 1999). In this regard, institutional rules, procedures and conventions can be seen as opportunity structures that influence individual behaviour and opportunities. Moreover, we follow the widely held 


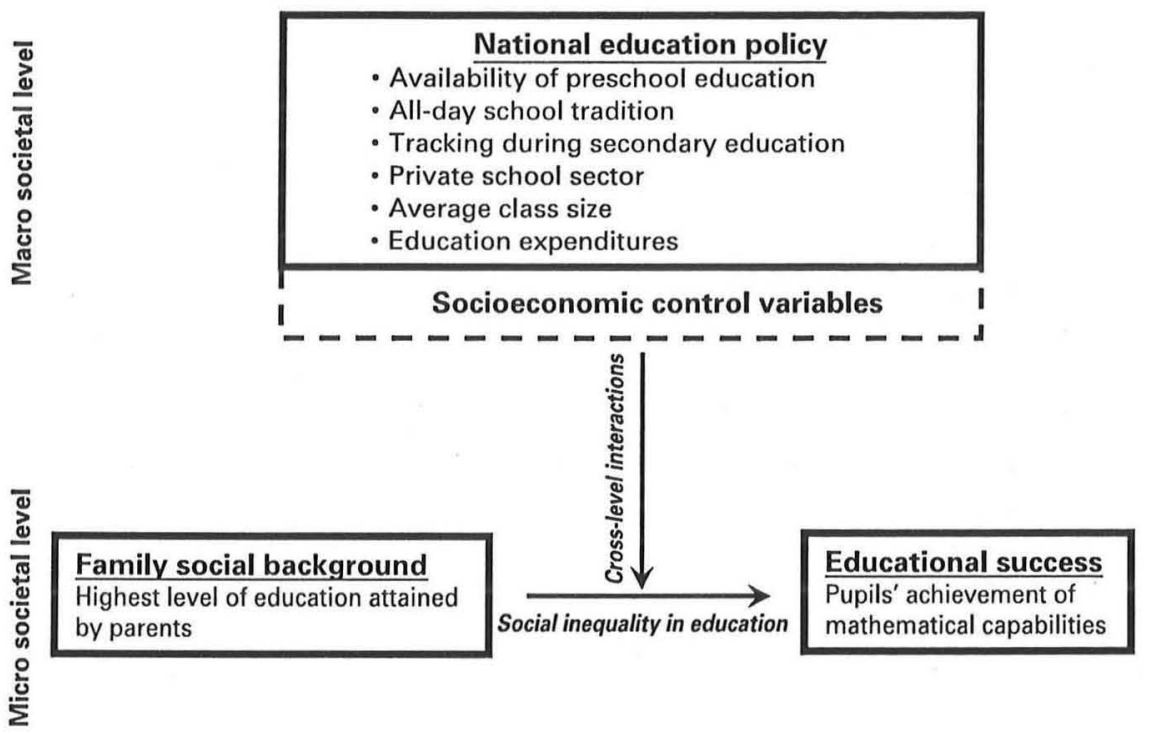

Figure 1 Macro explanatory model of social inequality in education. Source: The authors.

claim that political science should focus more intensely on the effects of political institutions and policy outputs on societal outcomes (Engerman and Sokoloff, 2008; Gormley, 2007).

Pupils are deeply embedded in national education policy rules (see Ostrom, 1999). Education policies thus structure pupils' education opportunities and, therefore, act as filters for individual educational success. In particular, specific education policies are presumed to enable individuals from lower social classes to participate equally in educational life and to achieve academic success according to their capabilities, whereas other systemic characteristics are likely to hinder equal educational opportunities (Esping-Andersen, 2008; Husén, 1979). Against this background, we can elaborate the effect of education policy by referring to the availability of preschool education, private school sector, tracking during secondary education, average class size, all-day school tradition and education expenditures.

Widely available preschool education is presumed to weaken the dependency of educational success on individual social background. Following Esping-Andersen (2008), comprehensive preschool availability is even a necessary condition for reducing the degree of educational inequality in a political unit. In this vein, we assume that early childhood education is able to act as a surrogate for insufficient capital resources at home 
(Esping-Andersen, 2008; Leschinsky and Mayer, 1990; Magnuson et al., 2006; McClelland and Acock, 2006; Schechter and Bye, 2006). Consequently, classspecific disparities in educational requirements could be reduced prior to starting primary school. Although children from lower social strata can profit from an enriching environment in early childhood, those exclusively socialized by their parents have reduced chances of internalizing external enriching influences. We do not, however, expect a linear influence of the availability of preschool education on social inequality (see Schütz et al., 2005). Moderate availability of preschool education may result in the exclusion of lower social classes from early childhood education, because children from the upper classes are likely to have better access to the few early childhood education facilities (Gamoran et al., 1999). Not only do better-educated parents tend to attach greater value to early education, but they are more likely (as well as able) to pay the fees for preschool education. Ultimately, the gap between children from more privileged social classes and their counterparts from disadvantaged backgrounds regarding enriching early childhood experiences would continue to grow. The equalizing effect preschool education can have on the school education process can be expected only if preschool facilities are provided on a broad and encompassing basis; only under such conditions can children from the lower social strata substantially profit from preschool education.

H1: A broad and encompassing preschool enrolment of the relevant age cohort should reduce the effect of parental educational status on pupils' mathematical performance.

Private schools are assumed to perform better than public schools because they may provide more individualized attention and encouragement (Braun et al., 2006). The market-oriented principal-agent relation within private schools shifts power to the pupils and their parents as the agents. Furthermore, private schools are presumed to have greater financial resources for providing individual support. Private schools also tend to exhibit an advantageous social environment or even constitute 'functional communities', providing a favourable school climate for better school performance (Corten and Dronkers, 2006). Although it can be argued that children from the lower classes could profit from such a fostering environment, in practice the net effect of private schools on social inequality in education tends to be positive owing to the social selection processes. Most importantly, private schools mainly attract pupils from high-income and better-educated families (Buddin et al., 1998; Fairlie and Resch, 2002; Wrinkle et al., 1999). Private schools therefore segregate pupils from different social classes by focusing specifically on upper-class target groups. Consequently, a large private school sector is 
presumed to strengthen the relationship between individual social background and school success.

H2: The more relevant the private school sector, the stronger the effect of parental educational status on pupils' mathematical performance.

Another main characteristic of education policy is whether or not institutional tracking of pupils during secondary education into hierarchically ordered educational programmes, each with varying academic status, takes place. The aim of tracking is to 'create instruction groups that are homogeneous with respect to student abilities' (Hallinan, 1996). In theory, such a policy can optimize the educational development of pupils independently of social background because well-performing children from lower social classes can move up socially when allocated to a relatively higher school level. In practice, however, the strict selection of pupils into hierarchically ordered and separated school types is thought to increase social inequality in education (Coleman, 1979; Gamoran and Mare, 1989; Jonsson, 1990; Saporito and Sohoni, 2007).

According to rational choice theories, educational decisions regarding school types depend mainly on parents' educational assumptions and tastes, and not just on children's educational goals or abilities (Becker, 2000; Goldthorpe, 1996). Upper-class parents frequently aspire to send their children to schools with a better academic reputation. Pupils from lower social classes, in contrast, owing to their parents' lower expectations concerning children's educational performance and the utility of education, tend to enrol in schools with a lower academic reputation (Leschinsky and Mayer, 1990; Solga and Wagner, 2001). As a result, children of well-educated parents have - independently of their abilities - a greater likelihood to be assigned to a more demanding school form than pupils from lower social strata. Tracking will, thus, be associated with more socially biased educational decisions (Lucas, 2001: 1646).

H3: Tracking of pupils in secondary education into several school forms enforces the effect of parental educational status on pupils' mathematical performance.

A small average class size, described by a low pupil-to-teacher ratio, is assumed to cushion the effect of social background on educational performance. The average class size can be seen as an indicator of the quality of the teaching and the learning process in a country, which has an important impact on educational outcomes (Szelewa and Polakowski, 2008: 118). A small class size indicates that one teacher is responsible for a small number of pupils, enabling the teacher to provide more individual attention. In contrast, a teacher responsible for many pupils may not be able to cater to the special 
needs of individual pupils or provide sufficient challenges and encouragement (Graddy and Stevens, 2005). Following Mosteller (1995), we hypothesize that it is primarily pupils from lower social classes who suffer from the lack of individual encouragement in large classrooms. Parents of pupils from more privileged backgrounds may compensate for the shortcomings of educational quality at school by providing additional support. In turn, small class sizes should improve performance, particularly by pupils from lower social classes, because this situation allows teachers to respond to special educational requirements. In conclusion, we assume a small average class size to weaken the relationship between individual social background and school success. ${ }^{4}$

H4: The smaller the average class size, the weaker the effect of parental educational status on pupils' mathematical performance.

In the public debate, all-day school is often touted as a means to decrease social inequality. In all-day schools, pupils, regardless of their social background, are socialized in a similar and enriching environment over the period of a full day. In the half-day school tradition, the organization of leisure time depends entirely on families (Schütz et al., 2005). For example, the availability of remedial teaching or participation in educational leisure activities is very much dependent on parents' resources. Children from less well-off families are at a definite disadvantage compared with their more privileged counterparts. Consequently, we expect the relation between individual social background and school success to be weakened by an increase in the number of hours pupils spend in the classroom.

H5: The more time pupils spend at school, the weaker the effect of parental educational status on pupils' mathematical performance.

Finally, the degree of social inequality in education is assumed to be influenced by the magnitude of public education expenditures. Low expenditures generally result in decreased educational investments and will possibly be substituted by a high proportion of private education expenditures, e.g. private lessons or privately purchased textbooks (Schmidt, 2002). This shift of responsibility from the state to the private sector may lead to different opportunities among social classes: well-educated parents will spend more money on education, because they not only have the financial resources to do so but also tend to value education more than parents from lower social classes, ultimately leading to different prospects for educational capabilities. Furthermore, public education expenditures emphasize the importance of education (Schmidt, 2002). This symbolic policy message may be transmitted to society and incorporated into individual education behaviour (see Jones 
and Cullis, 2003). In sum, low education expenditures are presumed to be linked to a high dependence of school success on family resources; high expenditures may reduce the need for private education expenditures and may, thus, increase social equality in education.

H6: The higher the public expenditure on school education, the weaker the effect of parental educational status on pupils' mathematical performance.

\section{Data, methodological approach and variables}

In the remainder of this article, the hypotheses will be empirically tested via multi-level analysis, which can be seen as a direct empirical implementation of our theoretical model. Both our dependent variable (the degree of social inequality) and the central explanatory variables (education policy conditions) of our investigation are country-specific indicators. However, because our parameter of interest - educational inequality - constitutes a relationship between two individual-level concepts that is expected to be influenced by contextual factors, we have to deal with a multi-level data structure. We thus calculate models in which individual educational performance is the dependent variable, explained by an interaction between individual social background and macro policy conditions. Our main focus is not on the dependent variable (educational performance) as such but on the cross-level interactions between education policies and individual social background.

Multi-level analysis is the most appropriate method for estimating such a model (Kedar and Shively, 2005; Steenbergen and Jones, 2002). The underlying principle of multi-level analysis is based on the modelling of contextual variance:

$$
Y_{i j}=\beta_{0 j}+\beta \cdot X_{i j}+\varepsilon_{i j}
$$

where

$$
\beta_{0 j}=\beta_{0}+\mu_{\mathrm{oj}}\left(\mu_{\mathrm{oj}}\right. \text { stands for the residuals at the contextual level) }
$$

This model implies that the behaviour of individual $i$ can vary between contextual units $j$. For instance, unlike standard regression analysis, this model does not assume that individual educational performance is the same in all countries (constant $\beta_{0}$ ); rather, it can vary from context to context. Furthermore, multi-level models are able to model macro-level characteristics (in the present case, education policies) that explain the variance between the EU countries.

An expansion of the approach, which is necessary to explain social inequality in education, is to model different effects of individual-level 
variables between countries - i.e. random slopes. When explaining these random slopes by country-specific characteristics (e.g. education policy, see Table 2), we refer to cross-level interactions because the effect of an individual-level variable on the dependent individual-level variable is moderated by macro political factors. In Figure 1, we are particularly interested in the cross-level interactions since nation-specific education conditions $W_{j}$ should moderate the effect of the micro relation between social background $(X)$ and school success $(Y)$. The model including these cross-level interactions is shown in equation 3 .

$$
\begin{aligned}
& Y_{i j}=\beta_{0}+\beta_{1} \cdot X_{1 i j}+\ldots+\beta_{k j} X_{k i j}+\ldots+\beta_{n} \cdot X_{n i j}+\alpha_{1} \cdot W_{1 j}+\ldots \\
& +\alpha_{m} \cdot W_{m j}+\ldots+\alpha_{n} \cdot W_{n j}+\gamma \cdot W_{m j} \cdot X_{k i j}+\mu_{\mathrm{o} j} \\
& +\mu_{m i j} \cdot X_{k i j}+\varepsilon_{i j} .
\end{aligned}
$$

$Y_{i j}$ specifies the educational performance of pupil $i$ in country $j$. This score is explained by the overall mean $\left(\beta_{0}\right)$, individual variables $\left(X_{1}\right.$ to $X_{n}$ and their estimates $\beta_{1}$ to $\beta_{n}$, respectively) and characteristics of the country ( $W_{1}$ to $W_{n}$ and their estimates $\alpha_{1}$ to $\alpha_{n}$, respectively). As only one cross-level interaction is modelled in each model, the subscripts $k$ and $m$ refer to the $k^{\prime \text { th }}$ individual variable that is randomized and interacted with the $m^{\prime}$ th contextual variable ( $X^{*} W$ and their estimate $\gamma$, respectively). $\gamma \cdot W_{m j} \cdot X_{k i j}+\mu_{m j} \cdot X_{k i j}$ thus stands for the effect of the contextual variable $W_{k}$ (education policy) on the influence of the individual variable $X_{m}$ (parental education). Moreover, our final model includes a further random intercept for the school level since pupils are nested not only within nation-states but also within different schools (not shown in the equation).

Following the logic of hierarchical modelling, we present a progression of models, each one building on the last. In order to document the variation of the dependent variables at the contextual level, we begin by estimating the impact of the individual-level characteristics - controlling for, but not yet modelling, contextual variables (Table 3, models 1 and 2). In a second step, we proceed by individually adding the six education policy variables to expand the basic model (model 2 in Table 3) and to estimate cross-level interactions with parents' education level..$^{5}$ Identifying substantial cross-level interactions would support our basic theoretical assumption that education policy moderates the relationship between pupils' individual social background (parental educational attainment) and pupils' school success (social inequality in education). According to Brambor et al. (2005), however, it does not suffice to present the interaction effects of the individual social background and an education policy condition on educational performance; rather, it is necessary to compare the marginal effects of parental education on school success as the policy context changes. With respect to our 
hypotheses, we assume that the effects of parental education on individual educational success vary across several levels of a given policy indicator. More precisely, our hypotheses would be confirmed given the following situations:

1. The marginal effect of parental education significantly decreases as the value of a given policy variable increases. (Note: for the variables tracking in secondary education, private school sector and class size, we expect inequality-fostering effects. Accordingly, the marginal effect of parental education should significantly increase with higher values of these policy variables.)

2. The marginal effect of parental education loses its statistical significance for higher levels of a given policy variable (in the case of tracking, private schools and class size, the marginal effect should gain statistical significance, however).

If one (or both) condition(s) is (are) fulfilled, this provides support for our hypothesis. It is worth mentioning that the grey highlighted marginal effects in Table 5 indicate the relevant range of values for the respective country groups. In other words, only these marginal effects should be considered in order to evaluate changes in the social inequality of education in the respective countries.

To measure our individual-level variables (individual social background and educational performance), we use data from the 2006 PISA study. Our PISA sample consists of 153,449 15-year-old pupils in the $25 \mathrm{EU}$ member states. Following Levels et al. (2008), we measure individual educational performance using the mathematical test score in PISA (own calculation of the mean over all plausible values in mathematics; variables PV1MATH, PV2MATH, PV3MATH, PV4MATH and PV5MATH in the PISA 2006 data set). It can be assumed that mathematics is the most suitable subject to compare since it is the most 'universal' one and tends to be independent of country-specific characteristics, such as linguistic heterogeneity. As discussed above, pupils' social background is measured by parents' highest level of education on a scale from 0 to 6 . Whereas a value of 0 means no school education at all, a value of 6 indicates the second stage of tertiary education leading to an advanced research qualification or at least higher secondary education, which provides access to advanced research programmes. ${ }^{6}$

Our explanatory factors at the macro societal level are national education policies. For our contextual indicators, we chose a point in time prior to 2006 that is relevant for the cohort of PISA 2006 in order to model causality and to avoid endogeneity problems. The availability of preschool is measured by the average enrolment ratios of children of the relevant age group from 1993 
to 1995 (see UNESCO, 1997). A dummy variable indicates whether more than $75 \%$ of children are enrolled in preschool or whether the share of children enrolled is smaller. A positive effect on equality in education can be expected only if preschool programmes are offered on a broad and encompassing basis (Schütz et al., 2005). ${ }^{7}$ The relevance of the private school sector is measured by the average enrolment ratios of pupils in private schools from 2000 to 2005 compared with all pupils enrolled in public and private schools (ISCED [International Standard Classification of Education] levels 1-4) (see Eurostat, 2008). To measure tracking in secondary education, a dummy variable based on case studies (Postlethwaite, 1995) is constructed. This dummy variable indicates whether tracking into several school types during secondary education takes place (1) or not (0). ${ }^{8}$ The average class size is measured by the pupil-to-teacher ratio, which indicates how many pupils one teacher was responsible for during lower secondary education in 2004 (see UNESCO, 1997). All-day school is operationalized by the minimum number of school hours taught in secondary education during the school year 2002/2003 (Eurodice, 2005: 259). Where fewer hours are taught per year, we conclude that all-day school is less developed, and vice versa. Finally, public education expenditures for primary and secondary education (ISCED 1-4) are measured as the ratio of per capita expenditures to the relevant number of pupils (see Eurostat, 2008). Table 2 provides an overview of the education policies in the EU member states. Further information on the variables used, their operationalization and sources, and descriptive statistics can be found in the Online Appendix.

In addition to the central explanatory variables, other potentially influential factors from the individual level and the national context should be considered as controlling variables. At the individual level, we control for gender, cultural home possessions, affluent home possessions, language spoken at home (whether it is different from the PISA test language) and migration status (first-generation foreigners). In addition to education policy, we control for the following macro societal variables: level of education within the population, post-communist countries, fertility rate, income inequality, proportion of foreigners, ethnic fractionalization, gross domestic product (GDP) per capita, unemployment rate, proportion of youth, and women's employment rate. These variables describe the economic and societal situation of a country beyond its education policy.

\section{Empirical results}

In this section, we subject our theory-derived relationships to empirical tests, focusing on the influence of education policy on the degree of educational inequality. 
Table 2 Education policies in the EU member states

\begin{tabular}{|c|c|c|c|c|c|c|}
\hline Country & $\begin{array}{l}\text { Preschool } \\
\text { education, } \\
\text { enrolment } \\
\text { ratio }>75 \% \\
\text { (Dummy) }\end{array}$ & $\begin{array}{l}\text { Private } \\
\text { school } \\
\text { sector, } \\
\text { enrolment } \\
\text { ratio (\%) }\end{array}$ & $\begin{array}{l}\text { Tracking } \\
\text { in } \\
\text { secondary } \\
\text { education } \\
\text { (Dummy) }\end{array}$ & $\begin{array}{l}\text { Average } \\
\text { class size } \\
\text { (pupil-to- } \\
\text { teacher } \\
\text { ratio) }\end{array}$ & $\begin{array}{l}\text { All-day } \\
\text { school } \\
\text { laverage } \\
\text { number } \\
\text { of hours } \\
\text { taught } \\
\text { per year) }\end{array}$ & $\begin{array}{l}\text { Education } \\
\text { expenditures } \\
\text { (p.c.) in } \\
\text { purchasing } \\
\text { power } \\
\text { standards }\end{array}$ \\
\hline Austria & 0 & 7.83 & 1 & 9.30 & 826.50 & $10,271.50$ \\
\hline Belgium & 1 & 57.18 & 1 & 11.54 & 869.33 & $8,699.28$ \\
\hline Bulgaria & 0 & 0.87 & 0 & 12.75 & 697.00 & $1,845.44$ \\
\hline Czech Republic & 1 & 5.67 & 0 & 12.26 & 731.25 & $3,898.58$ \\
\hline Denmark & 1 & 11.35 & 0 & 10.04 & 815.00 & $10,748.44$ \\
\hline Estonia & 0 & 2.08 & 0 & 10.34 & 372.50 & $3,201.61$ \\
\hline Finland & 0 & 5.35 & 0 & 9.53 & 741.00 & $7,980.35$ \\
\hline France & 1 & 21.08 & 0 & 13.28 & 944.00 & $7,927.58$ \\
\hline Germany & 1 & 5.83 & 1 & 13.14 & 800.25 & $6,472.29$ \\
\hline Greece & 0 & 7.03 & 0 & 8.13 & 811.50 & $4,658.12$ \\
\hline Hungary & 1 & 9.22 & 0 & 9.62 & 903.50 & $4,193.04$ \\
\hline Ireland & 1 & 0.82 & 1 & n.a. & n.a. & $5,551.08$ \\
\hline Italy & 1 & 5.80 & 0 & 10.07 & 957.00 & $9,646.95$ \\
\hline Latvia & 0 & 1.10 & 0 & 11.17 & 605.00 & $2,738.31$ \\
\hline Lithuania & 0 & 0.33 & 0 & 11.00 & 694.50 & $1,415.08$ \\
\hline Luxembourg & 1 & 12.23 & 1 & n.a. & 897.00 & $13,144.36$ \\
\hline Netherlands & 1 & 76.40 & 1 & n.a. & 1107.25 & $6,897.15$ \\
\hline Poland & 0 & 5.07 & 1 & 13.23 & 798.00 & $3,170.22$ \\
\hline Portugal & 0 & 12.10 & 1 & 9.81 & 920.00 & $5,399.60$ \\
\hline Romania & 0 & 1.33 & 0 & 12.01 & 667.00 & $1,121.65$ \\
\hline Slovakia & 0 & 5.90 & 1 & 13.16 & 732.50 & $2,405.74$ \\
\hline Slovenia & 0 & 1.50 & 0 & 11.14 & 740.50 & $6,092.77$ \\
\hline Spain & 0 & 30.68 & 0 & 12.72 & 930.00 & $5,309.06$ \\
\hline Sweden & 0 & 4.75 & 0 & 9.89 & 741.00 & $9,125.01$ \\
\hline United Kingdom & 0 & 38.97 & 0 & 15.75 & 886.00 & $7,310.84$ \\
\hline
\end{tabular}

Note: n.a. = data not available.

The first conclusion we can draw from Table 3 is that the hierarchical model is appropriate. About $13 \%$ of the total variance of individual educational performance can be found at the country level, even when controlling for variations at the individual and school level (model 1). In other words, pupils' mathematical scores systematically vary not only between individuals and between schools, but also between the EU member states. Moreover, although males perform better in mathematics than female pupils, and first-generation immigrants and pupils speaking a foreign language at home (a language different from that of the PISA test) perform below average 
Table 3 Individual model and basic contextual model to explain pupils' educational performance

\begin{tabular}{|c|c|c|}
\hline & $\begin{array}{l}\text { Model } 1 \\
\text { Individual variables }\end{array}$ & $\begin{array}{l}\text { Model } 2 \\
\text { Random slope }\end{array}$ \\
\hline Constant & $464.37(6.60)^{* * *}$ & $461.12(6.54)^{* * *}$ \\
\hline \multicolumn{3}{|l|}{ Individual effects } \\
\hline Male student & $18.11(0.36)^{* * *}$ & $18.21(0.35)^{* * *}$ \\
\hline First-generation foreign pupil & $-25.77(1.05)^{* * *}$ & $-25.73(1.05)^{* * *}$ \\
\hline Different language & $-6.89(0.72) * * *$ & $-7.45(0.72)^{* * *}$ \\
\hline Cultural possessions & $7.74(0.23)^{* * *}$ & $7.66(0.23)^{* * *}$ \\
\hline Home possessions & $6.72(0.25)^{* * *}$ & $6.64(0.25)^{* * *}$ \\
\hline Parents' educational attainment & $4.62(0.13)^{* * *}$ & $5.27(0.85)^{* * *}$ \\
\hline \multicolumn{3}{|l|}{ Random effects } \\
\hline \multicolumn{3}{|l|}{ Parents' educational attainment: } \\
\hline Variance & & $17.33(5.06)^{* * *}$ \\
\hline Covariance & & $-34.96(28.61)^{* * *}$ \\
\hline Individual variance & $4003.35(14.76)^{* * *}$ & $3977.99(14.54)^{* * *}$ \\
\hline School variance & $2796.32(54.01)^{* * *}$ & $2827.43(54.54)^{* * *}$ \\
\hline Country variance & $1061.21(303.97)^{* * *}$ & $1037.91(301.12)^{* * *}$ \\
\hline$N$ & 153,449 & 153,449 \\
\hline Number of countries & 25 & 25 \\
\hline-2 log-likelihood & 1725819 & 1725030 \\
\hline
\end{tabular}

Note: All models were calculated in MlwiN using the 'second order penalized quasi-likelihood' method and RIGLS (Goldstein and Rasbash, 1996).

$*^{* *}=$ significant at least at the $1 \%$ level.

in school, the estimations in both models in Table 3 clearly show strong effects of social background on pupils' educational performance: the higher the parents' level of education and the higher the cultural and home possessions, the more successful pupils are at school. The influence of parents' educational achievement on pupils' educational performance does vary between the EU countries, as tested by a random slope model for parents' education, confirming that social inequality in education indeed varies among the EU member states (model 2).

Is this substantial impact of social background on pupils' mathematical competencies (e.g. educational inequality) influenced by country-specific education policy? According to Table 4, the results are rather unclear: only three of the six examined education policy variables show some moderating effect on the pupils' social background and one even runs counter to our 
Table 4 Marginal effects of parental education on educational performance in $25 \mathrm{EU}$ countries

\begin{tabular}{lcll}
\hline \multicolumn{2}{l}{ Marginal effect of parental education } & Marginal effect of parental education \\
\hline Children in preschool & \multicolumn{3}{l}{ Tracking } \\
Less than 75\% & 6.01 & No & \\
More than 75\% & 4.17 & Yes & 2.69 \\
Share of private schools (\%) & & All-day school (hours/year) & \\
0 & 6.00 & 370 & 8.07 \\
10 & 5.45 & 470 & $\mathbf{8 . 5 3}$ \\
20 & 4.90 & 570 & $\mathbf{7 . 7 3}$ \\
30 & 4.35 & 670 & 6.93 \\
40 & 3.80 & 770 & 6.13 \\
50 & 3.25 & 870 & 5.33 \\
60 & 2.70 & 970 & 4.53 \\
70 & 2.15 & 1070 & 3.73 \\
80 & 1.60 & & 2.93 \\
Class size (pupils/teacher) & & Education expenditures & \\
8 & 4.66 & 10 & \\
9 & 4.89 & 20 & 7.49 \\
10 & 5.12 & 30 & 7.05 \\
11 & 5.35 & 40 & 6.61 \\
12 & 5.58 & 50 & 6.17 \\
13 & 5.81 & 60 & 5.73 \\
14 & 6.04 & 70 & 5.29 \\
15 & 6.27 & 80 & 4.85 \\
16 & 6.50 & 90 & 4.41 \\
& & 100 & 3.97 \\
& & 110 & 3.53 \\
& & 120 & 3.09 \\
& & & 2.65 \\
\hline & & &
\end{tabular}

Note: Bold indicates that the marginal effect is significant (at the $5 \%$ level).

a. Per capita educational expenditures were multiplied by 100 in order to render the marginal effects interpretable.

hypotheses. Contrary to expectations, a high proportion of private schools mediates the degree of social inequality, rather than fostering it. In countries where more than $50 \%$ of the pupils attend private schools, the effect of parental education loses its significance, implying that this context cushions educational inequality. Moreover, we find a weak effect of educational expenditures on the degree of social inequality since the marginal effect of social background is no longer significant if a country spends more than $€ 11,000$ on education. This level of spending, however, applies only to Luxembourg. Finally, all-day schools may narrow the gap between the 
academic capabilities of higher and lower social classes: the effect of parental education again decreases and ultimately loses its statistical significance with increasing time spent at school (over 1030 hours in the course of the school year). Again, only one country (the Netherlands) has such a lengthy school day.

With regard to these results, we refer to Table 1 and recall that inequality in education has a very different character in the post-communist countries than in the West European countries. The differences between Eastern and Western EU countries suggest that the effect of education policy on social inequality in education may vary between the two geographical areas, too (Schmid, 1984: 281). The post-communist countries clearly have a unique political tradition that considerably influenced the structure of the education policy, its impact and also the values and perceptions with respect to educational processes. Moreover, the ongoing economic and political transition has left its imprint on the countries' societal and economic structures, forming, yet again, a distinct environment for education policy. An estimation covering all research units therefore runs the risk of 'calculating out' group-specific effects (e.g. inverse effects found in different country clusters) and of producing statistically insignificant estimations as averages. Therefore, whether education policy effects are contextually dependent namely, whether they vary between East and West - must be tested. Again, we estimate six models, each containing one education policy variable to expand model 2 of Table 3, this time, however, estimating cross-level interactions with parents' education level separately for the East and West European countries. The marginal effects presented in Table 5 confirm that the policy effects indeed differ between Western and post-communist EU member states. Moreover, the moderating policy effects become more obvious. For the Eastern EU countries, four of the six hypotheses are now confirmed. ${ }^{9}$ For the Western EU, we also find four moderating policy effects, although the effects of private schools and class size run counter to our expectations. Our detailed results are as follows.

First, Table 5 specifies the effect of preschool enrolment for postcommunist and Western countries separately. Consistent with our hypothesis, a high preschool enrolment fosters educational equality in the post-communist countries, with parents' education losing its significant effect in countries with comprehensive preschool education. Preschools in the West European countries, however, do not substantially moderate the relationship between pupils' social background and their educational performance. Although the marginal effect of parental education on pupils' maths capabilities is lower when the enrolment ratio is higher than $75 \%$, this difference is not statistically significant (see Figure 2, upper graph). 
Table 5 Marginal effects of parental education on educational performance for Eastern and Western countries

\begin{tabular}{|c|c|c|c|c|c|}
\hline & \multicolumn{2}{|c|}{$\begin{array}{l}\text { Marginal effect of } \\
\text { parental education }\end{array}$} & & \multicolumn{2}{|c|}{$\begin{array}{l}\text { Marginal effect of } \\
\text { parental education }\end{array}$} \\
\hline & $\begin{array}{l}\text { Communist } \\
\text { legacy }\end{array}$ & $\begin{array}{l}\text { Western } \\
\text { democracies }\end{array}$ & & $\begin{array}{l}\text { Communist } \\
\text { legacy }\end{array}$ & $\begin{array}{l}\text { Western } \\
\text { democracies }\end{array}$ \\
\hline \multicolumn{3}{|c|}{ Children in preschool } & Tracking & & \\
\hline Less than $75 \%$ & 6.59 & 5.38 & No & $4.75^{\mathrm{a}}$ & 5.70 \\
\hline More than $75 \%$ & 5.63 & 3.81 & Yes & $12.92^{\mathrm{a}}$ & 3.21 \\
\hline \multicolumn{3}{|c|}{ Share of private schools (\%) } & \multicolumn{3}{|c|}{ All-day school (hours/year) } \\
\hline 0 & 4.78 & 5.49 & 370 & 4.56 & 14.75 \\
\hline 10 & 9.64 & 5.01 & 470 & 5.16 & 12.75 \\
\hline 20 & 14.50 & 4.53 & 570 & 5.76 & 10.75 \\
\hline 30 & 19.36 & 4.05 & 670 & 6.36 & $8.75^{\mathrm{a}}$ \\
\hline 40 & 24.22 & 3.57 & 770 & 6.96 & 6.75 \\
\hline 50 & 29.08 & 3.09 & 870 & 7.56 & 4.75 \\
\hline 60 & 33.94 & 2.61 & 970 & 8.16 & $2.75^{a}$ \\
\hline 70 & 38.80 & 2.13 & 1070 & 8.76 & 0.75 \\
\hline 80 & 43.66 & 1.65 & & & \\
\hline \multicolumn{3}{|c|}{ Class size (pupils/teacher) } & \multicolumn{3}{|c|}{ Educational expenditures ${ }^{b}$} \\
\hline 8 & 29.61 & 5.00 & 10 & 7.47 & 8.35 \\
\hline 9 & 30.85 & 4.90 & 20 & 6.95 & 7.80 \\
\hline 10 & 32.09 & 4.80 & 30 & 6.43 & 7.25 \\
\hline 11 & 33.33 & 4.70 & 40 & 5.91 & 6.70 \\
\hline 12 & 34.57 & 4.60 & 50 & 5.39 & 6.15 \\
\hline 13 & 35.81 & 4.51 & 60 & 4.87 & 5.60 \\
\hline 14 & 37.05 & 4.41 & 70 & 4.35 & 5.05 \\
\hline 15 & 38.30 & 4.31 & 80 & 3.83 & 4.50 \\
\hline \multirow[t]{4}{*}{16} & 39.54 & 4.21 & 90 & 3.31 & 3.95 \\
\hline & & & 100 & 2.79 & 3.40 \\
\hline & & & 110 & 2.27 & 2.85 \\
\hline & & & 120 & 1.75 & 2.30 \\
\hline
\end{tabular}

Notes: Bold indicates that the marginal effect is significant (at the $5 \%$ level); grey shading indicates the relevant range of values for the respective country group.

a. Marginal effects of parental education are significantly different between the various levels of the policy indicator; for all other policy indicators, the marginal effects do not significantly differ.

b. Per capita educational expenditures were divided by 100 in order to render the marginal effects interpretable.

Second, the East-West differentiation shows that private schools do not significantly influence social inequality of education in the post-communist EU member states. The highest share of private schools in these states is under 

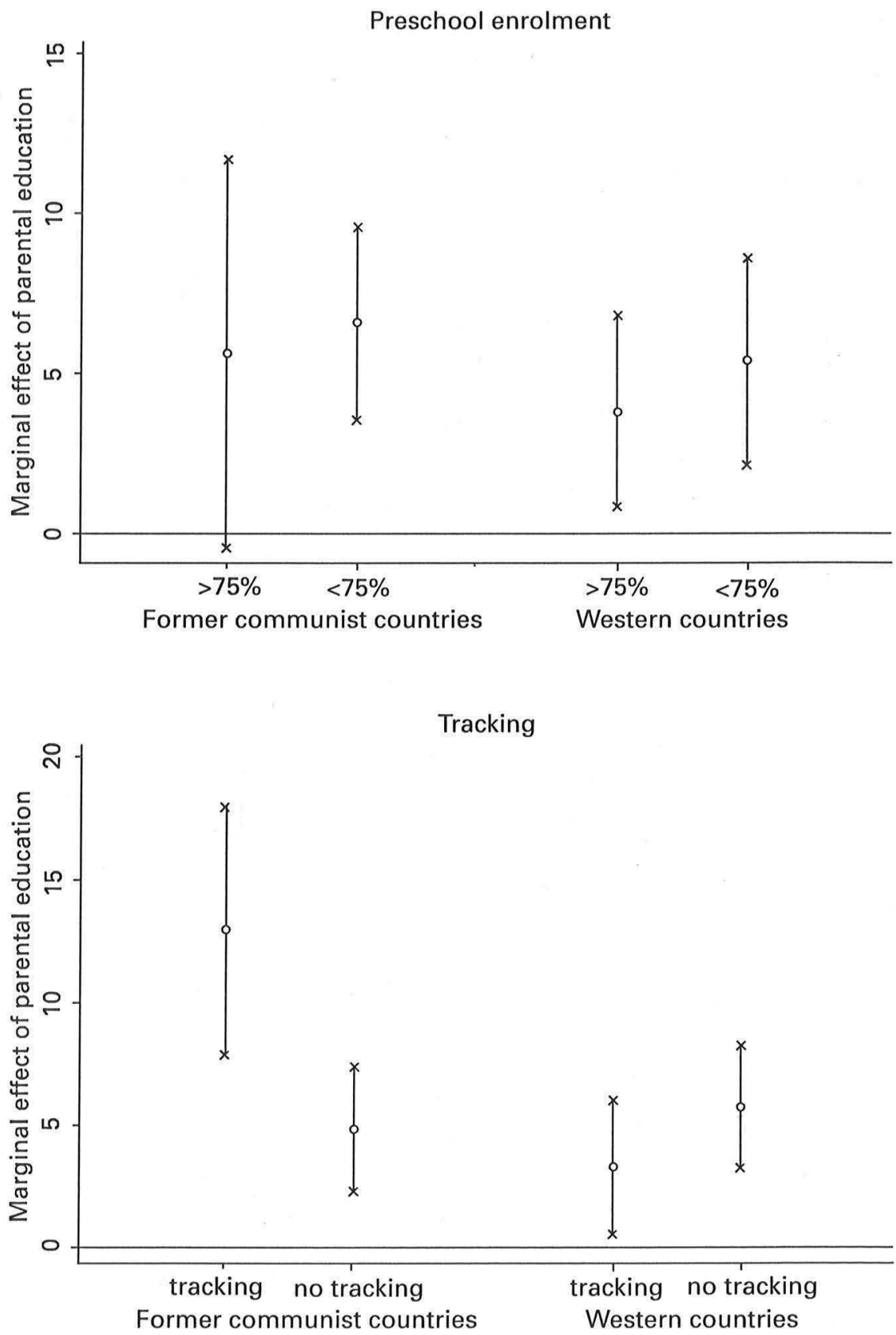

Figure 2 Marginal effects of parental education on educational performance depending on preschool enrolment and tracking.

Note: Figures based on the respective models in Table 5. 
$10 \%$ (see grey highlighted estimates), meaning that the effect of parental education remains significant in all these countries. The situation is, however, different in the Western EU member states. Contrary to the hypothesis and in accordance with the result for the entire sample, we find that high shares of private schools reduce the effect of social background. If the enrolment rate in private schools is higher than $45 \%$, the effect of parental educational status on pupils' maths capabilities loses its statistical significance. A large Western private school sector thus tends to cushion social inequality. This mainly holds for two cases - Belgium and the Netherlands - which both have a high level of private school enrolment ( $>45 \%$ ). This result can be seen against the background of the Coleman-Hoffer thesis, which postulates that private schools have to be differentiated into dependent (publicly funded, often religious) private schools and independent (privately funded) private schools (Corten and Dronkers, 2006; Dronkers and Robert, 2008). The dependent private schools are often subject to legal obligations prohibiting social segregation and, at the same time, mainly exist in the Western EU and especially in Belgium and the Netherlands, the two cases thus sustaining our results (Dronkers and Robert, 2008).

Third, we find a significantly weaker effect of parental education for postcommunist countries without tracking in secondary education than in Eastern countries that do track. In the Western countries, we again could not find any impact of the tracking system on social inequality in education (see Figure 2, lower graph). Therefore, the tracking hypothesis is confirmed for the postcommunist states but not for the Western states.

Fourth, when again taking the East-West divide into consideration, we find significant effects of all-day school on social inequality in education. In this case, the marginal effect of parental education diminishes and finally loses statistical significance in the Western EU member states as the number of hours taught at school increases. This lends some support to our hypothesis postulating that an enriched school environment over a longer daily period particularly benefits pupils from lower social classes by balancing unequal family conditions. This relationship, however, is not found in the postcommunist countries, where the estimation presents a rather converse relationship; in those countries with the shortest school days, the effect of social background tends to be weaker (and is even insignificant in the case of Estonia, which has the shortest school day). Remarkably, all-day school enrolment is below average in all Eastern EU member states. This may indicate that pupils, particularly from higher social classes, can profit from the all-day school in the Eastern states.

Fifth, in the Eastern countries, class size does not significantly influence social inequality in education. In the Western member states - contrary to the 
hypotheses - parental education does not seem to affect educational performance in countries with the highest class sizes. However, this effect must not be overestimated because only one country, Great Britain, falls into this category.

Finally, the effect of education expenditures is the only one that applies to both the Eastern and Western EU countries. Pupils' educational performance is not significantly dependent on parental education if they live in a country where investments in education are high.

\section{Conclusion}

In recent years, scholars in the social sciences have shown rising interest in analysing the effectiveness and performance of education policies. Our contribution follows this path by identifying systematic relationships between the composition of education policies and the degree of social inequality within the EU. Overall, the following conclusions can be drawn.

By analysing data from PISA 2006, we demonstrate that the degree of social inequality in education varies widely between EU member states. Moreover, there are striking differences in educational inequality between the West European and the post-communist member states. In general, performance in school depends more strongly on social background in the Eastern EU countries than in Western Europe. These results must be viewed against the background of the ongoing transformation processes in these countries. Up to the fall of communism, the Eastern societies were characterized by artificial top-down equalization. During the initial years of transformation, it was primarily the well-educated social classes that easily and quickly adapted to the free market economy, thereby improving their situation. This observation corroborates the literature on inequality, which assumes that the degree of societal inequality largely depends on a country's social and economic development (Kuznets, 1955).

Is education policy able to determine the extent of social inequality in education? Using the data from the 2006 PISA study, we can conclude that it is not only the degree of social inequality in education that varies between Western and post-communist EU member states but the mechanisms behind these inequalities as well. Only the hypothesis on education expenditures could be confirmed for the entire geographical scope of the EU. Moreover, our results support three other hypotheses, albeit only in a single geographical region: within the post-communist countries, comprehensive preschool education mitigates educational inequality whereas tracking in secondary education reinforces the degree of social inequality in education. In the Western EU 
countries, the all-day school is a validated means of decreasing educational inequality. Beyond these results, we found further effects of education policies that are contrary to expectations: all-day school tends to exacerbate social inequality in education in the post-communist member states rather than cushioning it; in the Western EU member states, the effects of the private school sector and average class size tend to contradict the hypotheses.

Given these findings, it is important to stress that an across-the-board elimination of educational inequalities is not a realistic undertaking. As the debate on pupils' capabilities with regard to nature vs. nurture, or an interaction of both (Duyme, 1988), does not seem to be drawing to an end, this consideration is of particular relevance. However, the marked variation in educational inequality between political entities implies that social inequality in education is not simply caused by marginal societal macro processes (see von Carnap and Edding, 1962). Against this background, it is not surprising that policy effects can be found, although they are not very strong and mainly occur at the highest levels of a given policy indicator. Moreover, from a socioeconomic point of view, societal structures and inequalities are typically very stable. In the Western countries, we indeed find well-anchored societal structures that have developed over centuries and are, therefore, difficult to change. By contrast, in the Eastern countries, where the communist breakdown provoked a complete reorganization of the political system and society, the ongoing transformation process provides better opportunities for higher social classes to develop, which may impede the influence of policies on societal inequalities. Finally, the findings can be viewed in relation to possible ambiguous effects of education policy on the achievement of capabilities (Scheerens and Bosker, 1997). In line with findings from other areas of social policy (see Mitchell, 1995; Stadelmann-Steffen, 2008: 400), the results indicate that the formal implementation of a policy may not lead to the intended equalityfostering outcome if the measures are not encompassing enough or do not explicitly target low social classes. In this regard, it is worth mentioning that further research is needed that focuses in more detail on the design of national education policy in a comparative perspective. In order to more precisely evaluate the effectiveness of various education policies and also to validate the present findings, it would be valuable to have data at hand that describe for example the level of preschool fees, the precise length of (pre)school days or the exact objective of education expenditures.

Furthermore, it is remarkable that neither the tracking system nor the private school sector led to social segregation in education in the Western states. Our findings demonstrate that a large private school sector even has the potential to narrow the capability gap between social classes, at least in the Western EU member states. From a neo-liberal perspective, the private 
school effect in the Western EU countries provokes discussion of whether private schools are able to stimulate positive competition among all schools, in turn helping to elevate the overall educational standards in a country. Moreover, according to the Coleman-Hoffer thesis, in the Western EU member states private schools are often constrained by legal obligations prohibiting social segregation (Dronkers and Robert, 2008). This also explains the differing results between Eastern and Western EU countries with regard to private schools.

The above discussions open the door to further research in which more attention should be paid to national variations in implementation practices and targeting, as well as to intra-national heterogeneity of education policy and educational inequality. Comparing social inequality in education in the German federal states, Freitag and Schlicht (2009) reveal strong evidence of an impact of sub-national preschool availability and the onset of tracking on the degree of educational inequality. In particular, the existence of decentralized education policies in Austria, Belgium, Germany or Hungary suggests that, in some cases, the nation-state is probably not the appropriate level for an investigation of social inequality in education and its political determinants.

\section{Notes}

We are grateful to Jaap Dronkers and to the three anonymous referees for their helpful comments and suggestions. An earlier version of this article was presented to the Annual Conference of the Swiss Political Science Association in St. Gallen, 8-9 January 2009, and to the Midterm Conference of the International Sociological Association in Neuchâtel, 26-28 June 2008. We thank the participants for valuable discussions. The data set for the empirical analysis in this article and the Online Appendix can be found at http://eup.sagepub.com/supplemental.

1 Cyprus and Malta are excluded from the analysis because they did not participate in PISA. Our sample is composed of the following EU countries: Austria, Belgium, Bulgaria, Czech Republic, Denmark, Estonia, Finland, France, Germany, Greece, Hungary, Ireland, Italy, Latvia, Lithuania, Luxembourg, the Netherlands, Poland, Portugal, Romania, Slovakia, Slovenia, Spain, Sweden and the United Kingdom.

2 In addition to the PISA studies, the TIMSS studies (Trends in International Mathematics and Science Study; every four years since 1995) also provide indicators to measure educational inequality in the school educational process. The World Bank provides an indicator described as a measure of inequality of school educational enrolment (access) (Vinod et al., 2001). Nevertheless, the indicator does not explicitly refer to 'social' inequality because it is merely a measure of variance of individual school educational enrolment (in years). 
3 It is worth mentioning that the measurement of social inequality in education, namely which variable is used to measure social background, influences the pattern found. Alternative indicators such as families' home possessions or parents' occupational status also reveal highly varying degrees of inequality among the EU states. However, the ranking of the countries is not exactly the same: East-West differences are less pronounced when focusing on incomerelated indicators. The reason for focusing on parental education is the increasing importance of cultural capital at home for educational success (Schimpl-Neimanns, 2000; Rössel and Beckert-Ziegelschmid, 2002). Moreover, education can be considered to be 'the backbone of inequalities in highly developed countries' (Dronkers and Levels, 2007: 436).

4 However, previous studies have shown ambiguous impacts of class size on pupils' performance (Scheerens and Bosker, 1997). In particular, it must be assumed that class size as such is only one aspect of what can basically be referred to as school effectiveness, and its effect may therefore also depend on other factors. Generally, the effect of education policy on inequality in education is not always that clear. Policies designed to promote the achievement of capabilities can, on the one hand, foster mobility between social strata by providing opportunities for pupils from lower social classes. On the other hand, these policies can also intensify inequalities since the upper classes often have both better opportunities and stronger incentives to profit from new education legislation (Scheerens and Bosker, 1997). Despite these contradictory trends in the literature, we base our hypotheses on the general assumption that education policies have the potential to moderate social inequality in education.

5 We thus calculate six models, each containing one of the education policy variables. It is not reasonable to include the educational context variables simultaneously in one model for two reasons. First, owing to the small number of units at the country level, it is not possible to integrate six contextual variables plus cross-level interactions into one model. Second, the policy variables are related to each other to some extent. Substantial correlations can be found between all-day schools and the share of private schools (Pearson's $r=0.63)$; between all-day schools and educational expenditures (0.50); between all-day schools and preschool education (0.46); and between preschool education and educational expenditures (0.47) and tracking (0.45), respectively. All other correlation coefficients are lower than 0.35 , indicating that the EU countries combine the six education policy variables differently. An index of education policy would, therefore, be inappropriate to represent the effective education policy situation in the EU member states. Our focus, thus, is on determining which elements of a country-specific policy mix are most relevant to social inequality of education. All models, however, control for the school context, the East-West divide in the EU and the population's level of education, because these variables proved to be the most important controlling factors and are, therefore, used in the following analyses. By contrast, fertility rate, income inequality, proportion of foreigners, ethnic fractionalization, GDP per capita, unemployment rate, proportion of youth and women's employment rate did not reach statistical significance. It is, furthermore, of note that the East-West divide significantly moderates the 
relationship between social background and school success (cross-level interaction). Confirming our previous descriptive finding (Table 1), social inequality in education is more pronounced in the post-communist member states of the EU. This interaction is also integrated into the models of Table 4 in order to correctly estimate education system and policy effects for the two country groups.

6 ISCED variable in the PISA 2006 data set. Value $1=$ ISCED level $1 ; 2=$ ISCED level 2; 3 = ISCED levels 3B/3C; 4 = ISCED levels 3A/4; 5 = ISCED level 5B; $6=$ ISCED levels $5 \mathrm{~A} / 6$. For further information regarding the meaning of the single ISCED levels, see UNESCO (1997). Despite the ordinal scaling of the variable, we perform a linear analysis. Ordinal analyses do not lead to different results.

7 This procedure is an alternative to the quadratic modelling of the preschool variable (social inequality first increases with early childhood education, then decreases after a certain 'cut-off point'). The insertion of an additional quadratic term of the preschool variable, however, produces very complex models when estimating cross-level interactions. Therefore, further analyses not presented here have been calculated in order to locate the 'cut-off point' that emerged at a preschool enrolment rate of around $75 \%$ - i.e. at this level, the effect of preschool education starts to occur. Thus, a dummy variable that takes the value of 1 if preschool enrolment is at $75 \%$ or higher not only captures the essential moderating effect of preschool education but also allows for the presentation of concise and comprehensible models.

8 We do not further distinguish between the number of tracks and internal/external tracking. Such differentiation is not possible based on the available case studies. If tracking takes place, in most countries in the EU it occurs between the ages of 11 and 13. An exception is Poland, where pupils are first tracked at the age of 15 (data from case studies of Postlethwaite, 1995).

9 Romania can be seen as an outlier in the Eastern country sample because it exhibits a very low value for educational inequality. However, further analyses (not presented) show that this low value is confirmed when using slightly different measurements of inequality in education such as a categorical variable of parental education or the variance explained by parental education. These analyses further demonstrate that the low level of inequality is mainly due to the fact that although low parental education negatively influences school success, as in all other countries, children with highly educated parents do not do significantly better at school than pupils with medium educated parents. Moreover, the omission of the Romanian case does not lead to substantially different conclusions.

\section{References}

Alber, Jens (2006) 'The European Social Model and the United States', European Union Politics 7(3): 393-419.

Allmendinger, Jutta and Stephan Leibfried (2003) 'Education and the Welfare State: The Four Worlds of Competence Production', Journal of European Social Policy 13(1): 63-81. 
Anderson, Christopher J. and Matthew M. Singer (2008) 'The Sensitive Left and the Impervious Right - Multilevel Models and the Politics of Inequality, Ideology, and Legitimacy in Europe', Comparative Political Studies 41(4-5): 564-99.

Barone, Carlo (2006) 'Cultural Capital, Ambition and the Explanation of Inequalities in Learning Outcomes: A Comparative Analysis', Sociology 40(6): 1039-58.

Baumert, Jürgen, Eckhard Klieme, Michael Neubrand, Manfred Prenzel, Ulrich Schiefele, Wolfgang Schneider, Petra Stanat, Klaus-Jürgen Tillmann and Manfred Weiß (2001) PISA 2000. Basiskompetenzen von Schülerinnen und Schülern im internationalen Vergleich. Opladen: Leske \& Budrich.

Beaton, Albert E., Ina V. S. Mullis, Michael O. Martin, Eugenio J. Gonzalez, Dana L. Kelly and Teresa A. Smith (1996) Mathematics Achievement in the Middle School Years: IEA's Third International Mathematics and Science Study (TIMSS). Boston: Center for the Study of Testing, Evaluation, and Educational Policy.

Becker, Rolf (2000) 'Klassenlage und Bildungsentscheidungen', Kölner Zeitschrift für Soziologie und Sozialpsychologie 52(3): 450-75.

Blossfeld, Hans-Peter and Yossi Shavit (1993) 'Dauerhafte Ungleichheiten. Zur Veränderung des Einflusses der sozialer Herkunft auf die Bildungschancen in dreizehn industrialisierten Ländern', Zeitschrift für Pädagogik 39(1): 25-52.

Bourdieu, Pierre (1983) 'Ökonomisches Kapital, kulturelles Kapital, soziales Kapital', in Reinhard Kreckel (ed.) Soziale Ungleichheiten, pp. 183-98. Göttingen: Otto Schwartz \& Co.

Brambor, Thomas, William R. Clark and Matt Golder (2005) ‘Understanding Interaction Models: Improving Empirical Analyses', Political Analysis 14(1): 63-82.

Braun, Henry, Frank Jenkins and Wendy Grigg (2006) 'Comparing Private Schools and Public Schools Using Hierarchical Linear Modeling', US Department of Education.

Buddin, Richard, Joseph J. Cordes and Sheila N. Kirby (1998) 'School Choice in California: Who Chooses Private Schools?', Journal of Urban Economics 44(1): $110-34$.

Coleman, James S. (1979) Equality of Educational Opportunity. New York: Arno Press.

Corten, Rense and Jaap Dronkers (2006) 'School Achievement of Pupils from the Lower Strata in Public, Private Government-Dependent and Private Government-Independent Schools: A Cross-National Test of the ColemanHoffer Thesis', Educational Research and Evaluation 12(2): 179-208.

Dimitrova, Antoaneta and Bernard Steunenberg (2000) 'The Search for Convergence of National Policies in the European Union', European Union Politics 1(2): 201-26.

Drezner, Daniel W. (2001) 'Globalization and Policy Convergence', International Studies Review 3(1): 53-78.

Dronkers, Jaap (1993) 'Educational-Reform in the Netherlands - Did it Change the Impact of Parental Occupation and Education', Sociology of Education 66(4): 262-77.

Dronkers, Jaap and Mark Levels (2007) 'Do School Segregation and School Resources Explain Region-of-Origin Differences in the Mathematics Achievement of Immigrant Students?', Educational Research and Evaluation 13(5): 435-62. 
Dronkers, Jaap and Peter Robert (2008) 'School Choice in the Light of the Effectiveness of Various Types of Public and Private Schools in 19 OECD Countries', Journal of School Choice 2(3): 260-301.

Duyme, Michel (1988) 'School Success and Social Class: An Adoption Study', Developmental Psychology 24(2): 203-9.

Engerman, Stanley L. and Kenneth L. Sokoloff (2008) 'Debating the Role of Institutions in Political and Economic Development: Theory, History, and Findings', Annual Review of Political Science 11: 119-35.

Erikson, Robert and John Goldthorpe (1992) The Constant Flux. Oxford: Clarendon Press.

Esping-Andersen, Gosta (2008) 'Childhood Investments and Skill Formation', International Tax and Public Finance 15(1): 19-44.

Eurodice (2005) 'Key Data on Education in Europe 2005', URL (consulted July 2008): http://eacea.ec.europa.eu/resources/eurydice/pdf/0_integral/ 052EN.pdf.

Eurostat (2008) 'Education and Training, Database', URL (consulted July 2008): http://epp.eurostat.ec.europa.eu/portal/page/portal/education/data/database.

Fairlie, Robert W. and Alexandra M. Resch (2002) 'Is There "White Flight" into Private Schools? Evidence from the National Educational Longitudinal Survey', Review of Economics and Statistics 84(1): 21-33.

Freitag, Markus and Raphaela Schlicht (2009) 'Educational Federalism in Germany: Foundations of Social Inequality of Education', Governance 22(1): $47-72$.

Gamoran, Adam and Robert D. Mare (1989) 'Secondary School Tracking and Educational Inequality: Compensation, Reinforcement, or Neutrality?', American Journal of Sociology 94(5): 1146-83.

Gamoran, Adam, Robert D. Mare and Lynne Bethke (1999) Effects of Nonmaternal Child Care on Inequality in Cognitive Skills. Madison: Institute of Research on Poverty.

Goldstein, Harvey and Jon Rasbash (1996) 'Improved Approximations for Multilevel Models with Binary Responses', Journal of the Royal Statistical Society 159(3): 505-13.

Goldthorpe, John (1996) 'Class Analysis and the Reorientation of Class Theory: The Case of Persisting Differentials in Educational Attainment', British Journal of Sociology 47(3): 481-501.

Gormley, William T. (2007) 'Public Policy Analysis: Ideas and Impacts', Annual Review of Political Science 10: 297-313.

Graddy, Kathryn and Margaret Stevens (2005) 'The Impact of School Resources on Student Performance: A Study of Private Schools in the United Kingdom', Industrial \& Labor Relations Review 58(3): 435-51.

Green, Andy (1999) 'Education and Globalization in Europe and East Asia: Convergent and Divergent Trends', Journal of Education Policy 14(1): 55-71.

Hall, Peter A. and Rosemary C. R. Taylor (1996) 'Political Science and the Three New Institutionalisms', Political Studies 44(5): 936-57.

Hallinan, Maureen T. (1996) 'Track Mobility in Secondary School', Social Forces 74(3): 983-1002.

Handl, Johann (1985) 'Mehr Chancengleichheit im Bildungssystem', Kölner Zeitschrift für Soziologie und Sozialpsychologie 37(4): 698-722. 
Hedström, Peter and Richard Swedberg (1996) 'Rational Choice, Empirical Research, and the Sociological Tradition', European Sociological Review 12(2): $127-46$.

Husén, Torsten (1979) The Future of Formal Education. The Role of Institutional Schooling in Industrial Society. Stockholm: Almqvist \& Wiksell International.

Immergut, Ellen M. (1998) 'The Theoretical Core of the New Institutionalism', Politics \& Society 26(1): 5-34.

Jacobs, Jerry A. (1996) 'Gender Inequality and Higher Education', Annual Review of Sociology 22: 153-85.

Jones, Philip and John Cullis (2003) 'Key Parameters in Policy Design: The Case of Intrinsic Motivation', Journal of Social Policy 32(4): 527-47.

Jonsson, Jan (1990) 'Educational Reform and Changes in Inequality in Sweden', in Achim Leschinsky and Karl-Ulrich Mayer (eds) The Comprehensive School Experiment Revisited: Evidence from Western Europe, pp. 139-73. Frankfurt am Main: Peter Lang.

Kedar, Orit and W. Phillips Shively (2005) 'Introduction to the Special Issue', Political Analysis 13(4): 297-300.

Knill, Christoph (2005) 'Introduction: Cross-national Policy Convergence: Concepts, Approaches and Explanatory Factors', Journal of European Public Policy 12(5): 764-74.

Kritzinger, Sylvia (2003) 'The Influence of the Nation-State on Individual Support for the European Union', European Union Politics 4(2): 219-41.

Kuznets, Simon (1955) 'Economic Growth and Income Inequality', American Economic Review 45(1): 1-28.

Leschinsky, Achim and Karl-Ulrich Mayer (eds) (1990) The Comprehensive School Experiment Revisited: Evidence from Western Europe. Frankfurt am Main: Peter Lang.

Levels, Mark, Jaap Dronkers and Gerbert Kraaykamp (2008) 'Immigrant Children's Educational Achievement in Western Democracies: Origin, Destination, and Community Effects on Mathematical Performance', American Sociological Review 73(5): 835-53.

Lucas, Samuel R. (2001) 'Effectively Maintained Inequality: Education Transitions, Track Mobility, and Social Background Effects', American Journal of Sociology 106(6): 1642-90.

McClelland, Megan M. and Alan C. Acock (2006) 'The Impact of Kindergarten Learning-related skills on Academic Trajectories at the End of Elementary School', Early Childhood Research Quarterly 21(4): 471-90.

Magnuson, Kathrine A., Christopher Ruhm and Jane Waldvogel (2006) 'The Persistence of Preschool Effects: Do Subsequent Classroom Experiences Matter?', Early Childhood Research Quarterly 22(1): 18-38.

Mitchell, Douglas E. (1995) 'Institutional Theory and the Social Structure of Education', Journal of Education Policy 10(5): 167-88.

Mosteller, Frederick (1995) 'The Tennessee Study of Class Size in the Early School Grades', Future of Children 5(2): 113-27.

Müller, Walter and Reinhard Pollak (2004) 'Social Mobility in West Germany: The Long Arms of History Discovered?', in Richard Breen (ed.) Social Mobility in Europe, pp. 77-113. Oxford: Oxford University Press.

Ostrom, Elinor (1999) 'Institutional Rational Choice: An Assessment of the 
Institutional Analysis and Development Framework', in Paul A. Sabatier (ed.) Theories of the Policy Process, pp. 35-71. Boulder, CO: Westview Press.

Postlethwaite, Thomas N. (ed.) (1995) International Encyclopedia of National Systems of Education. Cambridge: Pergamon.

Preston, John and Andy Green (2005) 'Educational Inequality and Social Cohesion: A Time Series Analysis', URL (consulted Nov. 2008): http://www.ioe.ac.uk.

Reed, Douglas S. (2003) On Equal Terms: The Constitutional Politics of Educational Opportunity. Princeton, NJ: Princeton University Press.

Rössel, Jörg and Claudia Beckert-Ziegelschmid (2002) 'Die Reproduktion kulturellen Kapitals', Zeitschrift für Soziologie 31(6): 497-513.

Saporito, Salvatore and Deenesh Sohoni (2007) 'Mapping Educational Inequality: Concentrations of Poverty among Poor and Minority Students in Public Schools', Social Forces 85(3): 1227-53.

Schechter, Carlota and Beth Bye (2006) 'Preliminary Evidence for the Impact of Mixed-Income Preschools on Low-Income Children's Language Growth', Early Childhood Research Quarterly 22(1): 137-46.

Scheerens, Jaap and Roelof J. Bosker (1997) The foundations of Educational Effectiveness. Oxford: Pergamon.

Schimpl-Neimanns, Bernhard (2000) 'Soziale Herkunft und Bildungsbeteiligung', Kölner Zeitschrift für Soziologie und Sozialpsychologie 52(4): 636-69.

Schmid, Günther (1984) 'The Political Economy of Labor Market Discrimination: A Theoretical and Comparative Analysis of Sex Discrimination', in Günther Schmid (ed.) Sex Discrimination and Equal Opportunity. The Labour Market and Employment Policy, pp. 264-308. Aldershot: Gower Publishing Company.

Schmidt, Manfred G. (2002) ‘Warum Mittelmaß? Deutschlands Bildungsausgaben im internationalen Vergleich', Politische Vierteljahresschrift 43(1): 3-19.

Schneider, Barbara L. and Venessa A. Keesler (2007) 'School Reform 2007: Transforming Education into a Scientific Enterprise', Annual Review of Sociology 33(1): 197-217.

Schütz, Gabriela, Heinrich W. Ursprung and Ludger Wößmann (2005) 'Education Policy and Equality of Opportunity', URL (consulted Jan. 2007): http:// www.cesifo-group.de.

Solga, Heike (2005) 'Meritokratie - die moderne Legitimation ungleicher Bildungschancen', in Peter A. Berger and Heike Kahlert (eds) Institutionalisierte Ungleichheiten, pp.19-38. Weinheim and Munich: Juventa.

Solga, Heike and Sandra Wagner (2001) 'Paradoxie der Bildungsexpansion. Die doppelte Benachteiligung von Hauptschülern', Zeitschrift für Erziehungswissenschaft 4(1): 107-29.

Stadelmann-Steffen, Isabelle (2008) 'Women, Labour, and Public Policy: Female Labour Market Integration in OECD Countries. A Comparative Perspective', Journal of Social Policy 37(3): 383-408.

Steenbergen, Marco and Bradford S. Jones (2002) 'Modeling Multilevel Data Structures', American Journal of Political Science 46(1): 218-37.

Szelewa, Dorata and Michael P. Polakowski (2008) 'Who Cares? Changing Patterns of Childcare in Central and Eastern Europe', Journal of European Social Policy 18(2): 115-31.

UNESCO (1997) 'International Standard Classification of Education', URL (consulted March 2009): http://www.uis.unesco.org/TEMPLATE/pdf/isced/ ISCED_A.pdf. 
Vinod, Thomas, Yan Wang and Xibo Fan (2001) 'Measuring Education Inequality: Gini Coefficients of Education', World Bank Policy Research Working Paper No. 2525, URL (consulted Mar 2009): http://econ.worldbank.org.

Von Carnap, Roderich and Friedrich Edding (1962) Der relative Schulbesuch in den Ländern der Bundesrepublik 1952-1960. Frankfurt am Main: Hochschule für Internationale Pädagogik.

Wilensky, Harold L. (1975) The Welfare State and Equality. Structural and Ideological Roots of Public Expenditures. Berkeley and Los Angeles: University of California Press.

Wrinkle, Robert D., Joseph Stewart and J. L. Polinard (1999) 'Public School Quality, Private Schools, and Race', American Journal of Political Science 43(4): 1248-53.

\section{About the authors}

Raphaela Schlicht is a Research Assistant to the Chair of Comparative Politics, Department of Politics and Management, University of

Konstanz, PO Box 84, 78457 Konstanz, Germany.

Fax: +497531884159

E-mail: raphaela.schlicht@uni-konstanz.de

Isabelle Stadelmann-Steffen is a Postdoctoral Research Assistant to the Chair of Comparative Politics, Department of Politics and Management, University of Konstanz, PO Box 84, 78457 Konstanz, Germany.

Fax: +497531884159

E-mail: isabelle.stadelmann-steffen@uni-konstanz.de

Markus Freitag is Chair of Comparative Politics, University of Konstanz, PO Box 84, 78457 Konstanz, Germany.

Fax: +497531884159

E-mail: markus.freitag@uni-konstanz.de 